\title{
Long-distance Passenger Transport: Geography, Infrastructure, Competition - A Conference Report
}

\author{
Monika Jandová, Tomáš Paleta ${ }^{1}$
}

\section{Introduction}

Charles University in Prague and Masaryk University in Brno have been organising a one-day international conference held in Prague biennially. In the previous two conference years, it was devoted first to competition in passenger railways in CEE countries (in 2014) and then to HSR in CEE countries (in 2016). This year conference took place on the $25^{\text {th }}$ May 2018 at the Faculty of Social Sciences (Charles University in Prague) and was dedicated to long-distance passenger transport. The aim of the conference was to document changes that the long-distance market has undergone especially in Central Europe due to increasing mobility, policy challenges, infrastructure investment and service innovations and to analyse its impact on national and European transport markets.

The conference was divided into three sessions. The first one was focused on British, French and Central European experience, the second session to Swedish, Italian and Swiss case and finally the third to the detailed Polish and Slovak experience.

\section{First conference block}

The first conference block was opened by Chris Nash (University of Leeds, Masaryk University) who devoted his presentation to the liberalisation of the long-distance passenger market in Great Britain. He aimed at the evolution of deregulation of air and coach and the rail and rail response.

C. Nash concluded that deregulation of coach and air services had led to improved services and lower fares. Simultaneously, rail in Britain has succeeded against air and coach because of i) high quality of rail services, ii) success of cities, and iii) congested motorways and airports. On the other hand, deregulation of entry into commercial rail has some disadvantages especially if combined with higher variable track access charges.

\footnotetext{
${ }^{1}$ Department of Economics, Faculty of Economics and Administration, Masaryk University, Lipová 41a, 60200 Brno, Czech Republic, jandova@econ.muni.cz, paleta@econ.muni.cz.
}

(C) 2018 by the authors; licensee Review of Economic Perspectives / Národohospodářský obzor, Masaryk University, Faculty of Economics and Administration, Brno, Czech Republic. This article is an open access article distributed under the terms and conditions of the Creative Commons Attribution 3.0 license, Attribution - Non Commercial - No Derivatives. 
The next presentation delivered by Yves Crozet (University of Lyon) was related to the regulation of long-distance passenger market in France. After a brief historical overview of French transport trends, Y. Crozet focused on regulation against competition in case of intermodal competition in France and contrary to regulation in favour of competition in case of coach services. Next, he addressed the question of high-speed rail and competition, especially intermodal. Y. Crozet emphasised that SNCF had been developing a smart yield management system to reduce the attractiveness of ride-sharing and coach services.

The first block was concluded by Zdeněk Tomeš and Monika Jandová with a presentation on open-access passenger rail services in Central Europe. Their presentation aimed at comparison of the impacts of open access entries on the development of national railway markets in three Central European countries - the Czech Republic, Slovakia and Austria. The comparison consists of i) entry barriers, ii) business model, iii) market developments, and iv) regulatory challenges.

They concluded that there is an undoubtedly positive impact of open access services (e.g. innovations, marketing, frequency, quality, prices, and ridership). On the other hand, we could find a questionable or negative impact of open access services (e.g. rising unit costs, stagnating revenues, financial losses, cherry-picking, long-term sustainability). Consequently, significant challenges for regulation have arisen (e.g. vertical structure, infrastructure capacity, priority rights, operators disputes, predatory pricing, anticompetitive behaviour).

\section{Second conference block}

The second conference block started with a presentation by Andreas Vigren (Swedish National Road and Transport Research Institute) on an entry in an open access market and its effect on prices in Sweden, a country with a tradition of deregulation. His investigation considered the entry made by MTR express on the Stockholm - Gothenburg line. He took into account an analysis of the short-run effects considering the "expresstrains" only.

Already before, MTR had lower prices, on average, than SJ. A. Vigren revealed that ticket prices faced by travellers were lowered after MTR's entry and simultaneously, MTR mostly offers lower prices than SJ. Since March 2015, SJ's prices have decreased by some 13 per cent.

The following presentation by Paolo Beria (Politecnico di Milano) dealt with evolving long-distance passenger services in Italy. He focused on three trends: i) specialisation, ii) competition and prices, and iii) mismatched planning.

In Italy, the long-distance market is increasingly specialised, with levels of supply ranging from HS trains to low-cost buses. Every type of service tends to stay in well-defined boundaries (e.g. luxury bus or low-cost HS does not exist).

P. Beria said that there was evidence that rail and coach prices are mutually influenced, which means that the long-distance market has been becoming a unique market. What is quite surprising is the fact that infrastructure planning seems totally unlinked with services and demand needs. 
Finally, the second session was closed by Christian Desmaris (University of Lyon) with a presentation on the reform of passenger rail in Switzerland. First, he introduced Swiss rail system and design of rail reforms. Afterwards, he aimed outputs on public finances and travellers' welfare.

Switzerland is mentioned as public transport mobility. A very high level of quality of service (e.g. interconnection of modes and tariff integration, high density, synchronisation and simultaneous correspondence, high frequency, punctuality) together with an acceptable price for the regular traveller. This leads to high public costs.

After the Swiss reforms, there is an inverse trend of the public compensation and more efficiency in the use of public funds due to a very responsible public governance, a traditional operator capable of greatly increasing productivity and more satisfied passengers. C. Desmaris concluded with the idea that the sustainability of the Swiss success is still a question.

\section{Third conference block}

The third conference block was opened by Marcel Horňák (Comenius University in Bratislava). He presented a presentation on the topic relating the link between trains and buses in case of the long-distance transport in Slovakia. First, he focused on characteristics of the Slovak long-distance transport market that is specified by a small area $(5.4$ million residents), no large urban agglomerations, rural territories and dispersed population.

M. Horňák concluded that open-access and competition had generally led to improvements in the quality of public transport. At the same time, he pointed out that Slovakia's geographic specifics still play an important role. The capital city, Bratislava, has a very good connection with Vienna, on the other hand, it is very poorly available from the regions of Eastern Slovakia. The result of liberalisation changes is the situation in which both trains and buses partially compete with automotive traffic. He concluded his presentation by saying that passengers and the environment are supposed to be winners of this competition.

The last presentation by Jakub Taczanowski (Jagellonian University Krakow), Marcin Król (Warsaw School of Economics) and Arkadiusz Kołoś (Jagellonian University Krakow) considered the intersection of the rail open access and the bus passenger services in Poland. First, they introduced the particularity of the Polish case where we could see a radical withdrawal of the state from providing long-distance public transport (especially bus) since the year 1990 .

The impacts of open access competition in Poland are different from experiences in other countries. Rivals' strategy does not include any responsive price cuttings which mean there is no price war. Next, the incumbent PKP aimed at differentiation strategy (quality of service) together with a product differentiation on selected lines.

When comparing the bus and train, rail is faster whereas the bus is cheaper (even 3-4 times). The connection between the relative ticket prices (both minimum and maximum) and the number of links is weak. They declared that in most analysed cases the direct competition between rail and bus seems to be limited. Besides, there is low flexibility of 
rail ticket system - with a relatively few special offers - and a passive attitude and lack of interest of PKP Intercity for intermodal competition.

The final discussion has emerged that the approaches to liberalisation and its results vary between countries, depending on the previous developments and attitudes of the government and other stakeholders. 